\title{
Clinical and laboratory experience of vorinostat (suberoylanilide hydroxamic acid) in the treatment of cutaneous T-cell lymphoma
}

\author{
M Duvic*,I and C Zhang' \\ 'Department of Dermatology, University of Texas MD Anderson Cancer Center, Box 434 1515, Holcombe Blvd, Houston, TX 77030, USA
}

\begin{abstract}
The most common cutaneous T-cell lymphomas (CTCLs) - mycosis fungoides (MF) and Sézary Syndrome - are characterised by the presence of clonally expanded, skin-homing helper-memory T cells exhibiting abnormal apoptotic control mechanisms. Epigenetic modulation of genes that induce apoptosis and differentiation of malignant $T$ cells may therefore represent an attractive new strategy for targeted therapy for T-cell lymphomas. In vitro studies show that vorinostat (suberoylanilide hydroxamic acid or SAHA), an oral inhibitor of class I and II histone deacetylases, induces selective apoptosis of malignant CTCL cell lines and peripheral blood lymphocytes from CTCL patients at clinically achievable doses. In a Phase lla clinical trial, vorinostat therapy achieved a meaningful partial response (>50\% reduction in disease burden) in eight out of $33(24 \%)$ patients with heavily pretreated, advanced refractory CTCL. The most common major toxicities of oral vorinostat therapy were fatigue and gastrointestinal symptoms (diarrhoea, altered taste, nausea, and dehydration from not eating). Thrombocytopenia was dose limiting in patients receiving oral vorinostat at the higher dose induction levels of $300 \mathrm{mg}$ twice daily for 14 days. These studies suggest that vorinostat represents a promising new agent in the treatment of CTCL patients. Additional studies are underway to define the exact mechanism ( $\mathrm{s}$ ) of by which vorinostat induces selective apoptosis in CTCL cells and to further evaluate the antitumour efficacy of vorinostat in a Phase Ilb study in CTCL patients.
\end{abstract}

British Journal of Cancer (2006) 95, SI3-S19. doi:I0.1038/sj.bjc.6603465 www.bjcancer.com

(c) 2006 Cancer Research UK

Keywords: histone deacetylase inhibitor; vorinostat; suberoylanilide hydroxamic acid; SAHA; cutaneous T-cell lymphoma; mycosis fundgoides

Cutaneous T-cell lymphomas (CTCLs) represent a heterogeneous group of extra-nodal non-Hodgkin lymphomas. Mycosis fungoides (MF) and its leukaemic variant, Sézary syndrome (SS), are the most frequently encountered types of CTCL. They are characterised by progressive clonal expansion of CD4+CD45RO + $\mathrm{CLA}+\mathrm{CCR}+$ helper/memory $\mathrm{T}$ cells that do not express the typical T-cell surface markers (CD7 and/or CD26) (Kim et al, 2005). In contrast to their normal counterparts, these malignant $T$ cells exhibit abnormal apoptotic control mechanisms resulting in prolonged lifespans and are typically very resistant to treatment regimens, including chemotherapeutic agents (Meech et al, 2001). Epigenetic modulation of genes that induce apoptosis and differentiation of malignant $\mathrm{T}$ cells may therefore represent an attractive new strategy for targeted therapy of CTCL.

Recent studies in our laboratory (Zhang et al, 2005) indicate that vorinostat (suberoylanilide hydroxamic acid or SAHA), an oral inhibitor of class I and II histone deacetylases (HDACs), induces apoptosis of malignant CTCL cell lines and peripheral blood lymphocytes from SS patients cells at clinically achievable doses. These data suggest that alterations in HDAC activity may be involved in the pathogenesis of $\mathrm{T}$-cell lymphomas and that vorinostat may be clinically effective in treating T-cell lymphomas. This article provides a brief overview of the pathophysiology of CTCL, summarises the spectrum of currently available treatment options, and finally reviews data from preclinical studies as well as

\footnotetext{
*Correspondence: Dr M Duvic; E-mail: mduvic@mdanderson.org
}

ongoing or recently completed clinical trials evaluating the antitumour efficacy of vorinostat in patients with refractory or relapsed CTCL patients unresponsive to conventional therapy.

\section{PATHOPHYSIOLOGY AND PROGNOSIS}

Mycosis fungoides represents the most common and indolent form of CTCL and was originally described more than 200 years ago (Girardi et al, 2004). A key characteristic of MF is the presence of malignant skin-homing $\mathrm{T}$ cells possessing distinct markers $(\mathrm{CD} 4+\mathrm{CD} 45 \mathrm{RO}+\mathrm{CLA}+\mathrm{CCR}+)$ but lacking the usual T-cell surface markers CD7 and/or CD26. Although many clinical variants of this lymphoma are described, the most common clinical presentation is of pink to red patches or plaques appearing in sun-shielded areas. Lesions are often accompanied by variable degrees of pruritus (Girardi et al, 2004; Kazakov et al, 2004). Mycosis fungoides may progress over many years from the early patch/plaque T1-T2 stages to more advanced stages involving tumours (which frequently ulcerate), erythroderma, blood or organ involvement, and ultimately death from infection (Girardi et al, 2004). A leukaemic variant characterised by generalised erythroderma and the presence of abnormal circulating malignant $\mathrm{T}$ cells is referred to as SS. Patients with SS not only exhibit erythroderma but often have intractable itching and frequently are colonised by Staphylococcus aureus (Jackow et al, 1997). Circulating malignant lymphocytes have convoluted nuclei (referred to as Sézary cells, after the French dermatologist who discovered them) 
Table I Prognosis of CTCL patients according to tumour stage at presentation

\begin{tabular}{|c|c|c|}
\hline Stage & Description & Survival \\
\hline IA & TI, patches and/or plaques involving $<10 \%$ BSA with no palpable adenopathy & Similar to age-matched controls (Kim et al, 1999; Zackheim et al, 1999) \\
\hline IB & T2, patches and/or plaque involving at $\geqslant 10 \%$ BSA with no palpable adenopathy & $\geqslant 67 \%$ at 10 years (Kim et al, 1999; Zackheim et al, 1999) \\
\hline$\| A$ & TI/T2, patches and/or generalised plaque, clinically abnormal lymph nodes & \\
\hline IIB & T3, cutaneous tumours & 5 years (Kim and Hoppe, 1999) \\
\hline III & T4, generalised erythroderma & \\
\hline IVA-B & Pathologically involved lymph nodes or visceral involvement & 2.5 years (Kim and Hoppe, 1999) \\
\hline
\end{tabular}

BSA = body surface area.

and appear on flow cytometry as CD4 + CD26-lymphocytes (Jones et al, 2001; Washington et al, 2002).

The initial trigger leading to the development of skin-homing $\mathrm{CD} 4+$ cells in MF/SS is unclear, although environmental and infectious agents have been hypothesised. MF has an association with class II HLA DR5 and DQB ${ }^{\star} 03$ alleles, suggesting that it may be an autoimmune disease triggered by antigen presentation (Jackow et al, 1996). Also supporting this hypothesis is the pathologic finding of atypical, malignant epidermotropic CD4+lymphocytes clustering around epidermal Langerhans forming the characteristic Pautrier microabscesses (Girardi et al, 2004; Kim et al, 2005). Immature dendritic cells (Langerhans cells) in the epidermis may play an intimate role in the early pathogenesis of MF/SS by activating T cells through direct contact and providing the impetus for their clonal expansion (Berger et al, 2002). Progression of MF/SS is accompanied by clonal dominance of the malignant cells, (Vega et al, 2002) leading to the elaboration of Th2 cytokines, (Rook et al, 1997) impairment of the host's immune response, and further tumour cell growth (Girardi et al, 2004; Kim et al, 2005).

The survival of MF/SS patients varies markedly with the stage of disease at presentation, and although difficult to study, may in part be dependent on whether immunosuppressive therapy is administered (Table 1) (Kim and Hoppe, 1999; Kim et al, 1999; Zackheim et al, 1999). Patients in the early stages of MF are treated with topical agents and show a median survival not unlike that of matched control populations. Patients with advanced stages IVA-B defined by pathologically involved lymph nodes, blood, or visceral involvement have a poor prognosis, with a median survival of only 2.5 years in some studies (Kim and Hoppe, 1999). The appearance of large cell transformation within 2 years of diagnosis is also associated with a poor prognosis (Diamandidou et al, 1998).

\section{CURRENT TREATMENT OPTIONS}

The primary goal of any therapy is to induce a long-term complete remission or cure. However, a less ambitious goal of decreasing the tumour burden, improving symptoms, and preserving quality of life, without further impacting the patient's already compromised immune system, is a more realistic situation. There are a limited number of therapeutic modalities, including skin-directed therapies, biologic-response modifiers, systemic agents, and experimental therapies, available to treat patients with MF/SS (Table 2). However, only extracorporeal photopheresis, denileukin diftitox, and bexarotene have FDA approval for this specific indication. In general, MF/SS is managed according to the stage of the disease (Table 3). Treatment decisions may be influenced by weighing the expected benefits against drug toxicities, patient tolerance and convenience, cost, and compliance with therapy.

Patients with early stages of MF have disease localised to the skin, where it can often be put into remission with skin-directed therapies. The usual progression of treatment begins with topical steroids or retinoid, followed by either topical chemotherapy with mustargen (mechlorethamine $\mathrm{HCl}$ ) or with one form of photo- therapy. Combinations of topical and phototherapy may hasten the time to response. Total skin electron beam irradiation is generally reserved for patients with generalised skin involvement, thick plaques, or tumours who have failed topical therapies. Aggressive chemotherapy cannot be justified for early MF because it does not prolong overall survival in comparison to conservative sequential therapy (Kaye et al, 1989).

In patients who fail to respond to skin-directed therapy or have more extensive lesions, the addition of biological response modifiers is the accepted therapeutic choice. As discussed in a previous detailed reviews of the literature, (Kempf et al, 2003; Zhang and Duvic, 2003) oral retinoids, either alone, or in combination with other skin-directed or biological response modifiers, represent a good low-risk treatment modality to control early MF. Retinoic acid receptor selective retinoids (isotretinoin and etretinate) are similar in efficacy with response rates of about $50 \%$ reported for each agent. Bexarotene oral capsules as monotherapy were able to induce responses in $54 \%$ of early (Duvic et al, 2001b) and 45\% risk reduction of advanced, refractory CTCL at the optimised dose of $300 \mathrm{mg} \mathrm{m}^{-2}$ in two clinical Phase II trials (Duvic et al, 2001a, b). Combined treatment modalities, including the retinoid isotretinoin, followed by TSEB (for stage I-II disease) or preceded by chemotherapy (for stage II and IV disease) (Duvic et al, 2003a) bexarotene plus PUVA, or photopheresis plus alpha interferon (IFN) and low-dose bexarotene, (Rook et al, 1999a) have been reported to give overall response rates of $82 \%$ in MF patients and $69 \%$ in SS patients (Kempf et al, 2003). Combinations of bexarotene with other modalities were most effective when one or two lipid-lowering agents and synthroid were simultaneously administered, giving response rates of over $70 \%$ (Talpur et al, 2002). Retinoids can be given orally, are active in $50 \%$ of the patients, and are a generally well tolerated first-line systemic therapy of CTCL; however, patients may fail to reach complete remission or may relapse while on treatment, requiring other approaches and therapies.

Another agent to show promise in treating CTCL is the tumourtargeted fusion protein, denileukin diftitox (Olsen et al, 2001). In patients with stage Ib to IVa CTCL who had received $>3$ prior therapies, denileukin diftitox therapy ( 9 or $18 \mu \mathrm{g} \mathrm{kg}^{-1}$ day $^{-1}$ for 5 days every 3 weeks for up to eight cycles) produced an overall response rate of $30 \%$ (20\% partial response (PR), $10 \%$ complete response (CR)) and mediation duration of response of 6.9 months (range, 2.7 to $>46.1$ months). Pre-administration of low-dose corticosteroids with denileukin diftitox infusions blocked the commonly encountered infusion reactions and improved the response rate to $60 \%$ (Foss et al, 2001). Denileukin diftitox can produce a vascular leak syndrome (hypotension, hypoalbuminemia, and oedema), which can be partially prevented by saline infusions post-treatment. It can also induce a hypersensitivity reaction or transaminase elevations in some patients.

Patients with more advanced MF/SS or those who relapse and become resistant to initial treatments require a more aggressive therapeutic approach, which may involve biologic response modifiers, combination therapies, bone marrow transplantation, or chemotherapy. In addition to retinoids, both alpha and gamma 
Table 2 Overview of current therapeutic options for MF/SS

\section{Skin-directed therapy}

- Topical corticosteroids (Farber et al, 1968; Zackheim et al, 1998)

- Topical chemotherapy (e.g., nitrogen mustard, (Vonderheid et al, 1989) carmustine (Zackheim et al, 1990))

- Topical retinoids (bexarotene, (Duvic et al, 200 la; Breneman et al, 2002) tazarotene (Apisarnthanarax et al, 2004))

- Topical imiquimod (Didona et al, 2004)

- Phototherapy (UVB, (Ramsay et al, 1992) NbUVB, (Gathers et al, 2002) PUVA (Herrmann et al, 1995))

- Electron beam therapy (Jones et al, 1995)

Biological therapy

- RXR retinoid (bexarotene) (Breneman et al, 2002; Duvic et al, 200 l b)

- RAR retinoid (isotretinoin) (Neely et al, 1987)

- Interferons (Olsen, 2003)

- Granulocyte-macrophage colony-stimulating factor (Bouwhuis et al, 2002)

- Extracorporeal photopheresis (Duvic et al, 2003b)

- Fusion protein/toxin (denileukin diftitox) (Olsen et al, 200I)

Other systemic therapies

- Cytotoxic chemotherapy (methotrexate, (Zackheim et al, 2003) doxil,(Di Lorenzo et al, 2005) gemcitabine, (Sallah et al, 200I) etoposide, (Onozuka et al, 2004) pentostatin (Dearden et al, 2000))

- Bone marrow/stem cell transplantation (Soligo et al, 2003; Guitart et al, 2002)

Experimental therapies

- HDAC inhibitors (vorinostat, (Duvic et al, 2005) depsipeptide (Piekarz et al, 200 I))

- Transimmunisation extracorporeal photopheresis (Girardi et al, 2002)

- Targeted monoclonal antibodies (CD52, (Lundin et al, 1998; Lundin et al, 2003) CCR4(Niwa et al, 2004)\}, CD4 (McFarlane et al, 2005))

- Cytokines (IL-12, IL-2 (Rook et al, 2003))

- TLR agonists (CPG oligodeoxynucleotides) (Wysocka et al, 2004)

- Tumour vaccines (Seo et al, 2003)

$\mathrm{UVB}=$ ultraviolet $\mathrm{B}$ light, $\mathrm{NbUVB}=$ narrow-band ultraviolet $\mathrm{B}$ light, $\mathrm{PUVA}=$ psoralen plus ultraviolet $\mathrm{A}$ light, $\mathrm{R} X \mathrm{R}=$ retinoid $\mathrm{X}$ receptor, $\mathrm{RAR}=$ retinoic acid receptor, $T L R=$ toll-like receptor $9 ; \mathrm{IL}=$ interleukin. Information extracted from Kim EJ et al, J Clin Invest 2005; I I 5:798-8I2.

Table 3 Overview of initial and subsequent treatment options by stage for patients with MF/SS

\begin{tabular}{|c|c|c|c|c|}
\hline \multicolumn{5}{|c|}{ TNMB classification and staging } \\
\hline IA & IB-IIA & IIB & IIIA,B & IVA,B \\
\hline $\begin{array}{l}\text { Initial therapy } \\
\text { Skin directed-therapies - topical } \\
\text { chemotherapy } \\
\text { PUVA } \\
\text { UVB } \\
\text { Local EBT }\end{array}$ & & & & \\
\hline \multirow{2}{*}{ Subsequent therapy } & & & & \\
\hline & $\begin{array}{l}\text { IFN- } \alpha \\
\text { Retinoids combined therapies } \\
\text { - TSEBT/PUVA+topical } \\
\text { chemotherapy } \\
\text { - PUVA+INF- } \alpha \\
\text { - PUVA+retinoids } \\
\text { - TSEBT+INF- } \alpha\end{array}$ & $\begin{array}{l}\text { Other combined therapies } \\
- \text { TSEB+ECPP } \\
\text { - Retinoids+INF- } \alpha \\
\text { - TSEBT+chemotherapy }\end{array}$ & $\begin{array}{l}\text { Combined } \\
\text { therapies: } \\
\text { - ECPP+INF- } \alpha \\
\text { - PUVA+INF- } \alpha \\
\text { - PUVA+retinoids } \\
\text { - Retinoids+INF- } \alpha\end{array}$ & Bone marrow/stem cell transplant \\
\hline
\end{tabular}

Salvge therapy

Newer/investigational therapies

PUVA = oral psoralen-UV-A, EBT = electron beam therapy, TSEBT = total skin electron beam therapy, INF- $\alpha=$ interferon- $\alpha$, ECPP $=$ extracorporeal photopheresis Information extracted from Kim EJ et al (Kim et al, 2005) and Kim YH and Hoppe RT (Kim and Hoppe, 1999).

IFNs are active biological response modifiers with immunostimulatory activity in CTCL. Alpha IFN combined with photopheresis and a retinoid are first line treatments for patients with SS (Gottlieb et al, 1996; Duvic et al, 2003b). Another biological response modifier, interleukin 12 , has shown activity in three separate clinical trials and increases CD8 + T-cell infiltrates in CTCL lesions (Rook et al, 1999b).

Although combined chemotherapeutic regimens (e.g., CHOP (cyclophosphamide, vincristine, doxorubicin, prednisone), CMED (cyclophosphamide, methotrexate, etoposide, and dexametha- sone), and ESHAP (etoposide, methyl prednisolone, high-dose cytarabine, and cisplatin)) have been utilised in treating CTCL and have response rates of about $60 \%$, the duration of responses seen may be disappointingly brief. Combined chemotherapy often requires the placement of central lines, which in turn increase the risk of potentially fatal opportunistic infections in the setting of a compromised host immune system.

Nucleoside agents have recently been studied for treatment of advanced patients with CTCL. Several phase II studies concluded that gemcitabine has high response rates of $70 \%$ in patients with 
MF (Zinzani et al, 2000; Marchi et al, 2005). Gemcitabine is especially active against tumours (Duvic et al, 2006b) and is well tolerated, with minimal toxicity. Pentostatin has been studied as well and shows $60 \%$ response rates in patients with SS but is less active against tumours and nodal disease where the duration of response is only a few months (Kurzrock et al, 1999). Chemotherapy should be used for palliation in patients with nodal or visceral involvement or large cell transformation.

Bone marrow transplantation (autologous and allogeneic) has been employed to treat advanced CTCL but the overall clinical experience to date is limited to less than 20 patients. Autologous transplants have not cured the disease whereas non-ablative allogenic transplants show more promise in putting patients into complete remissions. Nevertheless, allogeneic transplantion was reported to produce remissions of 4.5 years, 15 months, and 9 months in three patients (Guitart et al, 2002). Further, the results of a retrospective study evaluating outcome in advanced CTCL patients population suggests that allogeneic haematopoietic stemcell transplantation can induce durable clinical, molecular, and cytogenetic remissions in patients with advanced CTCL refractory to standard therapies (Molina et al, 2005).

It is clear from these studies that patients with refractory or transformed MF and with SS have a generally poor prognosis and therapy is typically palliative. There is an urgent need for new therapies, especially ones capable of reversing the defective apoptosis that is a characteristic of all CTCL cells. HDAC inhibitors such as vorinostat, may modulate the expression of genes controlling growth and differentiation of T-cell lymphomas and may represent an attractive new strategy for targeted therapy of CTCL.

\section{EVALUATION OF VORINOSTAT IN CTCL}

\section{Preclinical studies}

Vorinostat demonstrates potent anti-tumour effects against three well-established CTCL cell lines (MJ [G11], Hut78, and HH) as well as in freshly isolated peripheral blood lymphocytes from 11 patients with a high percentage of circulating malignant $\mathrm{T}$ cells (Zhang et al, 2005). As shown in Figure 1, vorinostat inhibited cell growth of MJ, Hut78, and $\mathrm{HH}$ cell lines in a dose-dependent and time-dependent manner. For example, increasing the dose of vorinostat from 1 to $5 \mu \mathrm{m}$ increased growth inhibition of $\mathrm{HH}$ cells from 2 to $34 \%$ at $24 \mathrm{~h}$ and from 21 to $70 \%$ at $48 \mathrm{~h}$. Analysis of the distribution of cells in various phases of the cell cycle using flow cytometry revealed that growth inhibition induced by vorinostat was associated with an increase in the percentage of cells in sub- $\mathrm{G}_{1}$ population and a loss of cells in the $G_{1}, S$, and $G_{2} / M$ phases, suggesting vorinostat induces apoptosis (Zhang et al, 2005).
The proapoptotic effect of vorinostat was confirmed in vitro by flow cytometric analysis of annexin $\mathrm{V}$ protein binding to the cell surface of CTCL cell lines and freshly isolated peripheral blood lymphocytes from CTCL patients (Zhang et al, 2005). Annexin V binding is a novel technique to detect apoptosis and works by binding to phosphatidylserine residues at the outer plasma membrane. These residues become exposed as a result of loss of phospholipid asymmetry of the plasma membrane, an early event in apoptosis. Vorinostat increased the proportion of cells binding annexin $\mathrm{V}$ in all three CTCL cell lines (Figure 2) (Zhang et al, 2005). Importantly, vorinostat was associated with selective apoptosis, as evidenced by the ability of vorinostat to increase annexin $\mathrm{V}$ binding to freshly isolated peripheral blood lymphocytes obtained from SS/MF patients but to lymphocytes isolated from healthy donors.

\section{Mechanism of selective apoptotic action in CTCL cells}

Selective apoptosis produced by vorinostat may potentially involve a variety of mechanisms, including an increase in p21 ${ }^{\mathrm{WAF} 1}$, an alteration in bax/bcl-2 ratio, a decrease in Stat 6 and phosphor-

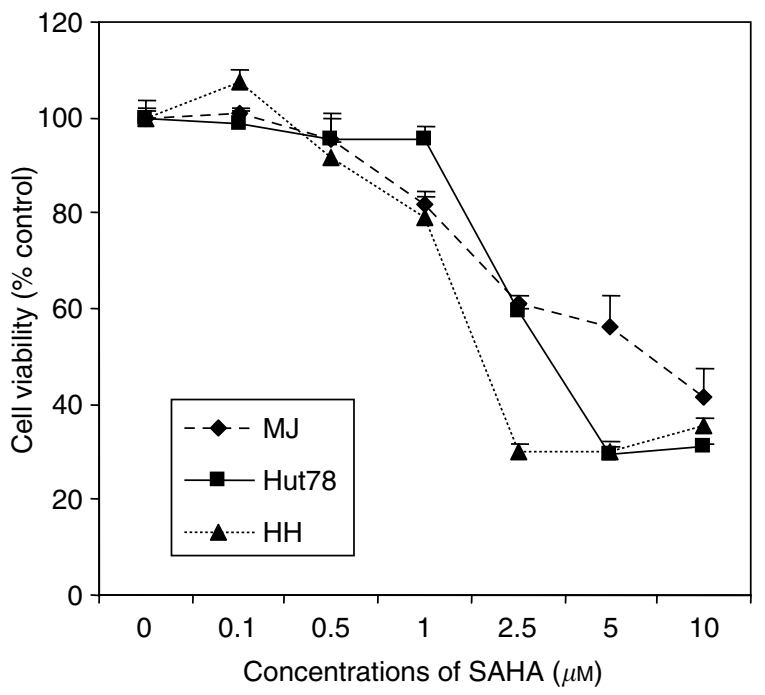

Figure I Vorinostat inhibited cell growth in three CTCL cell lines incubated in vitro for 24 or $48 \mathrm{~h}$. Cells were aliquoted into 96 -well plates and cell viability measured spectrophometrically at $490 \mathrm{~nm}$ after $4 \mathrm{~h}$ following addition of 3-(4,5-dimethylthiazol-2-yl)-5-(3-carboxymethoxyphenyl)-2-(4-sulfophenyl)-2H-tetrazolium inner salt. Reproduced with permission from Zhang C et al, J Invest Dermatol 2005 (Zhang et al, 2005).
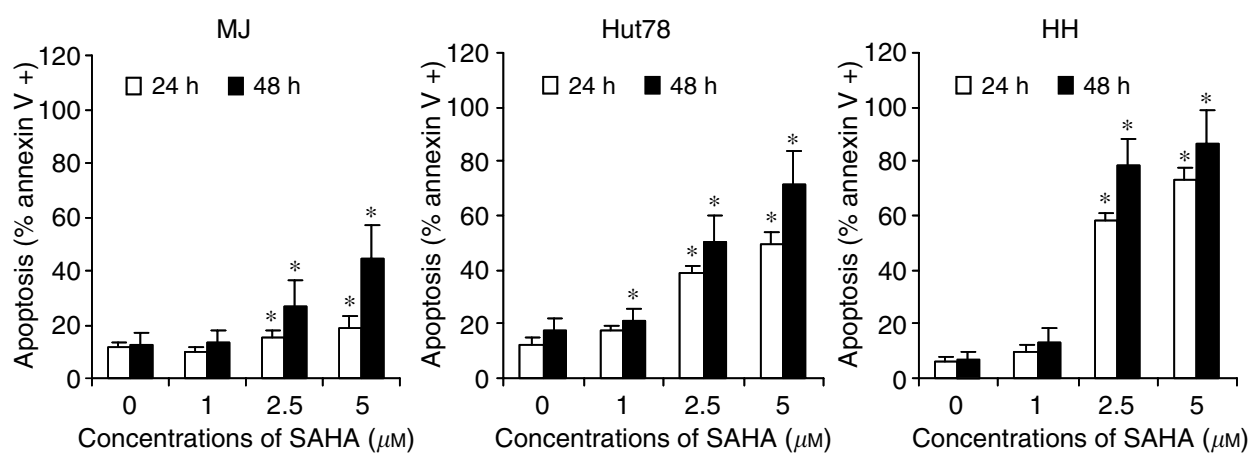

Figure 2 Effect of increasing doses of vorinostat on apoptosis assessed by annexin $\vee$ binding in three CTCL cell lines after 24 or $48 \mathrm{~h}$ of incubation. Reproduced with permission from Zhang C et al, J Invest Dermatol 2005 (Zhang et al, 2005). 
Stat6 proteins, and an activation of caspase-3 (Zhang et al, 2005). At this juncture, it seems unlikely that differences in the ability of vorinostat to inhibit HDAC activity or regulate the expression of key genes are the primary hypothetical mechanisms for differential sensitivity of tumour and normal cells to this agent. This assertion is based on the observations that the addition of vorinostat results in accumulation of acetylated histones in both normal fibroblasts from human lung and breast as well as transformed cells (WI-38, VA 13, and ARP-1), CTCL cell lines (MJ, Hut78, and HH), and peripheral blood lymphocytes from two patients with SS (Ungerstedt et al, 2005; Zhang et al, 2005). Nevertheless, the results presented by Ungerstedt et al (2005) do indicate that vorinostat may cause an accumulation of reactive oxygen species (ROS) and caspase activation in transformed but not normal cells as well as an increase in the level of Trx, a major reducing protein for many targets, in normal cells but not in transformed cells (Zhang et al, 2005).

Our in vitro studies (Zhang et al, 2005) of CTCL cell lines revealed that vorinostat at concentrations associated with apoptosis resulted in induction of expression of p21 WAF1, a protein that has been shown to be responsible for cell cycle arrest and apoptosis induced by HDAC inhibitors (Mei et al, 2004; Somech et al, 2004). Although upregulation of p $21^{\text {WAF1 }}$ occurred in response to vorinostat, immunoblot analysis showed that this effect was independent of the tumour suppressor p53. In addition, vorinostat was found to impact the nuclear to cytoplasmic expression of p-Stat stat 3 proteins in CTCL cell lines (Duvic et al, 2006a). Stat proteins represent a family of transcription factors that, once activated, are believed to contribute to oncogenesis by stimulating cell proliferation and preventing apoptosis (Sommer et al, 2004; Turkson, 2004; Mitchell and John, 2005). Vorinostat at concentrations capable of producing apoptosis, decreased the expression of Stat6 and phosphor-Stat6 (but not Stat3 and phosphor-Stat3) in CTCL cell lines and peripheral blood lymphocytes from SS patients. Clearly, further research is needed to explore all of these mechanisms in greater detail.

\section{Phase I study}

A recently completed phase I study of patients with advanced cancer described the effect of oral vorinostat in a patient with CTCL who had failed to respond to a total of five previous systemic therapies. Oral vorinostat administered at a dose of $200 \mathrm{mg}$ twice daily for a total of 4 months resulted in a stabilisation of the disease. Although a second patient with peripheral T-cell lymphoma was enrolled, the report did not appear to describe the outcome of this patient. This finding is consistent with a recent phase I trial of another HDAC inhibitor (FR901228), which showed a PR in three patients with CTCL and one patient with peripheral T-cell lymphoma (Piekarz et al, 2001).

\section{Phase II study}

In light of the favourable preclinical studies and the response of the CTCL patient to oral vorinostat in the phase I trial, a phase IIA clinical trial (Duvic et al, 2005) was conducted at our centre to determine the response rate, duration of response, pruritus relief, and safety profile of oral vorinostat in 33 patients with refractory or relapsed CTCL (stages IA-IVB) unresponsive to at least one conventional therapy. There were four patients who were treated twice in different dosing cohorts.

Patients were required to have adequate bone marrow, liver, and renal function, and an ECOG performance status of less than or equal to 2. Enrolled patients were treated with continuous daily dosing of oral vorinostat $400 \mathrm{mg}$, intermittent dosing of oral vorinostat $300 \mathrm{mg}$ twice daily (for 3 days with 4 days rest), or oral vorinostat according to an induction/rest/ continuous regimen ( $300 \mathrm{mg}$ twice daily for 14 days, with 7 days rest followed by $200 \mathrm{mg}$ twice daily). The primary efficacy end point of the study was the complete \& partial response rate (CR, $\mathrm{PR}$ ). However, the study also evaluated time to response, time to progressive disease, response duration, pruritus relief and safety. The response to therapy was categorised according to the World Health Organization criteria (Miller et al, 1981) as a CR, PR, stable disease, or progressive disease. The safety of vorinostat was assessed by utilising the National Cancer Institute Common Toxicity Criteria version 2.

Based on a preliminary analysis of intent-to-treat data, presented at the 2005 annual meeting of the American Society of Clinical Oncology (Duvic et al, 2005), a total of 10 out of 37 patients with heavily pretreated advanced refractory CTCL patients achieved a meaningful PR ( $>50 \%$ reduction in disease burden). Considering unique patients for an intent-to-treat analysis, eight out of 33 or $24 \%$ of the patients achieved a documented PR and there were no CRs (Duvic et al, 2006a).

The most common major toxicities that were possibly or probably related to oral vorinostat therapy were fatigue and gastrointestinal symptoms, including diarrhoea, altered taste, nausea, and dehydration from not eating/drinking. Thrombocytopenia was dose limiting in patients receiving oral vorinostat at the higher induction doses of $300 \mathrm{mg}$ twice daily for 14 days. Overall, oral vorinostat at a dose of $400 \mathrm{mg}$ daily provided the most favourable risk-benefit profile and, thus, this dose has been selected for a second Phase IIB trial currently ongoing at multiple centres.

The adverse effects associated with vorinostat therapy can be managed in several ways. Dehydration in elderly patients can be prevented by weighing patients at each visit, checking haemoglobin and creatinine levels and by using fruit juice, popsickles, smoothies, or sherbert to relieve a dry mouth and improve taste and appetite. In addition, nausea and vomiting can be controlled with ondansetron hydrochloride and diarrhoea treated with lomotil. The risk of haematologic side effects can also be minimised by avoiding aspirin and by monitoring for a rapid fall in platelet counts or a rapid change in international normalised ratio in those patients receiving coumadin.

\section{CONCLUSIONS}

The HDAC inhibitor vorinostat increases apoptosis of CTCL cells in vitro at concentrations that are clinically relevant. Oral vorinostat has a rapid onset of action and exhibits significant clinical activity against transformed tumours, erythroderma, and nodes in heavily pretreated, refractory CTCL patients. Most patients with CTCL also experience significant itching relief with vorinostat therapy, and, hence, a marked improvement in their quality of life. Overall, vorinostat appears to be generally well tolerated, with fatigue and gastrointestinal symptoms being the most common side effects at lower doses and thrombocytopenia at higher doses. These side effects were dose related and reversible upon cessation of therapy. Additional studies are underway to define the exact mechanism (s) of by which vorinostat induces selective apoptosis in CTCL cells and to further evaluate the antitumour efficacy of vorinostat in a Phase IIb study in CTCL patients.

\section{ACKNOWLEDGEMENTS}

Writing assistance for this paper was provided by Jan S Redfern, $\mathrm{PhD}$, and funding was provided by Merck \& Co. Inc., Whitehouse Station, NJ 08889. 


\section{REFERENCES}

Apisarnthanarax N, Talpur R, Ward S, Ni X, Kim HW, Duvic M (2004) Tazarotene $0.1 \%$ gel for refractory mycosis fungoides lesions: an openlabel pilot study. J Am Acad Dermatol 50: 600-607

Berger CL, Hanlon D, Kanada D, Dhodapkar M, Lombillo V, Wang N, Christensen I, Howe G, Crouch J, El Fishawy P, Edelson R (2002) The growth of cutaneous T-cell lymphoma is stimulated by immature dendritic cells. Blood 99: 2929-2939

Bouwhuis SA, Markovic SN, McEvoy MT, Pittelkow MR (2002) Extracorporeal photopheresis and adjuvant aerosolized granulocyte-macrophage colony-stimulating factor for Sezary syndrome. Mayo Clin Proc 77: $197-200$

Breneman D, Duvic M, Kuzel T, Yocum R, Truglia J, Stevens VJ (2002) Phase 1 and 2 trial of bexarotene gel for skin-directed treatment of patients with cutaneous T-cell lymphoma. Arch Dermatol 138: 325-332

Dearden C, Matutes E, Catovsky D (2000) Pentostatin treatment of cutaneous T-cell lymphoma. Oncology (Williston Park) 14: $37-40$

Di Lorenzo G, Di Trolio R, Delfino M, De Placido S (2005) Pegylated liposomal doxorubicin in stage IVB mycosis fungoides. $\mathrm{Br} \mathrm{J}$ Dermatol 153: $183-185$

Diamandidou E, Colome-Grimmer M, Fayad L, Duvic M, Kurzrock R (1998) Transformation of mycosis fungoides/Sezary syndrome: clinical characteristics and prognosis. Blood 92: 1150-1159

Didona B, Benucci R, Amerio P, Canzona F, Rienzo O, Cavalieri R (2004) Primary cutaneous CD30+ T-cell lymphoma responsive to topical imiquimod (Aldara). Br J Dermatol 150: 1198-1201

Duvic M, Apisarnthanarax N, Cohen DS, Smith TL, Ha CS, Kurzrock R (2003a) Analysis of long-term outcomes of combined modality therapy for cutaneous T-cell lymphoma. J Am Acad Dermatol 49: 35-49

Duvic M, Chiao N, Talpur R (2003b) Extracorporeal photopheresis for the treatment of cutaneous T-cell lymphoma. J Cutan Med Surg 7: 3-7

Duvic M, Hymes K, Heald P, Breneman D, Martin AG, Myskowski P, Crowley C, Yocum RC (2001a) Bexarotene is effective and safe for treatment of refractory advanced-stage cutaneous T-cell lymphoma: multinational phase II-III trial results. J Clin Oncol 19: 2456-2471

Duvic M, Martin AG, Kim Y, Olsen E, Wood GS, Crowley CA, Yocum RC (2001b) Phase 2 and 3 clinical trial of oral bexarotene (Targretin capsules) for the treatment of refractory or persistent early-stage cutaneous T-cell lymphoma. Arch Dermatol 137: 581 - 593

Duvic M, Talpur R, Ni X, Zhang C, Hazarika P, Kelly C, Chiao JH, Reilly JF, Ricker JL, Richon VM, Frankel SR (2006a) Phase II trial of oral vorinostat (suberoylanilide hydroxamic acid, SAHA) for refractory cutaneous T-cell lymphoma (CTCL). Blood (E-pub ahead of print)

Duvic M, Talpur R, Wen S, Kurzrock R, David CL, Apisarnthanarax N (2006b) Phase II evaluation of gemcitabine monotherapy for cutaneous T-cell lymphoma. Clin Lymphoma Myeloma 7: 51-58

Duvic M, Talpur R, Zhang C, Goy A, Richon VM, Frankel SR (2005) Phase II trial of oral suberoylanilide hydroxamic acid (SAHA) for cutaneous T-cell lymphoma (CTCL) unresponsive to conventional therapy. Presented at the Annual Meeting of the American Society of Clinical Oncology, Orlando, Florida, May 2005, abstract number 6571

Farber EM, Zackheim HS, McClintock RP, Cox Jr AJ (1968) Treatment of mycosis fungoides with various strengths of fluocinolone acetonide cream. Arch Dermatol 97: 165-172

Foss FM, Bacha P, Osann KE, Demierre MF, Bell T, Kuzel T (2001) Biological correlates of acute hypersensitivity events with DAB (389)IL-2 (denileukin diftitox, ONTAK) in cutaneous T-cell lymphoma: decreased frequency and severity with steroid premedication. Clin Lymphoma 1: $298-302$

Gathers RC, Scherschun L, Malick F, Fivenson DP, Lim HW (2002) Narrowband UVB phototherapy for early-stage mycosis fungoides. J Am Acad Dermatol 47: $191-197$

Girardi M, Berger C, Hanlon D, Edelson RL (2002) Efficient tumor antigen loading of dendritic antigen presenting cells by transimmunization. Technol Cancer Res Treat 1: 65-69

Girardi M, Heald PW, Wilson LD (2004) The pathogenesis of mycosis fungoides. N Engl J Med 350: 1978-1988

Gottlieb SL, Wolfe JT, Fox FE, DeNardo BJ, Macey WH, Bromley PG, Lessin SR, Rook AH (1996) Treatment of cutaneous T-cell lymphoma with extracorporeal photopheresis monotherapy and in combination with recombinant interferon alfa: a 10 -year experience at a single institution. J Am Acad Dermatol 35: $946-957$

Guitart J, Wickless SC, Oyama Y, Kuzel TM, Rosen ST, Traynor A, Burt R (2002) Long-term remission after allogeneic hematopoietic stem cell transplantation for refractory cutaneous T-cell lymphoma. Arch Dermatol 138: $1359-1365$

Herrmann JJ, Roenigk Jr HH, Hurria A, Kuzel TM, Samuelson E, Rademaker AW, Rosen ST (1995) Treatment of mycosis fungoides with photochemotherapy (PUVA): long-term follow-up. J Am Acad Dermatol 33: $234-242$

Jackow CM, Cather JC, Hearne V, Asano AT, Musser JM, Duvic M (1997) Association of erythrodermic cutaneous T-cell lymphoma, superantigenpositive Staphylococcus aureus, and oligoclonal T-cell receptor V beta gene expansion. Blood 89: $32-40$

Jackow CM, McHam JB, Friss A, Alvear J, Reveille JR, Duvic M (1996) HLA-DR5 and DQB1 ${ }^{\star} 03$ class II alleles are associated with cutaneous T-cell lymphoma. J Invest Dermatol 107: 373-376

Jones D, Dang NH, Duvic M, Washington LT, Huh YO (2001) Absence of CD26 expression is a useful marker for diagnosis of T-cell lymphoma in peripheral blood. Am J Clin Pathol 115: 885-892

Jones GW, Hoppe RT, Glatstein E (1995) Electron beam treatment for cutaneous T-cell lymphoma. Hematol Oncol Clin North Am 9: $1057-1076$

Kaye FJ, Bunn Jr PA, Steinberg SM, Stocker JL, Ihde DC, Fischmann AB, Glatstein EJ, Schechter GP, Phelps RM, Foss FM (1989) A randomized trial comparing combination electron-beam radiation and chemotherapy with topical therapy in the initial treatment of mycosis fungoides. $\mathrm{N} \mathrm{Engl}$ J Med 321: $1784-1790$

Kazakov DV, Burg G, Kempf W (2004) Clinicopathological spectrum of mycosis fungoides. J Eur Acad Dermatol Venereol 18: 397 - 415

Kempf W, Kettelhack N, Duvic M, Burg G (2003) Topical and systemic retinoid therapy for cutaneous T-cell lymphoma. Hematol Oncol Clin North Am 17: 1405 - 1419

Kim EJ, Hess S, Richardson SK, Newton S, Showe LC, Benoit BM, Ubriani R, Vittorio CC, Junkins-Hopkins JM, Wysocka M, Rook AH (2005) Immunopathogenesis and therapy of cutaneous T cell lymphoma. J Clin Invest 115: $798-812$

Kim YH, Chow S, Varghese A, Hoppe RT (1999) Clinical characteristics and long-term outcome of patients with generalized patch and/or plaque (T2) mycosis fungoides. Arch Dermatol 135: 26-32

Kim YH, Hoppe RT (1999) Mycosis fungoides and the Sezary syndrome. Semin Oncol 26: $276-289$

Kurzrock R, Pilat S, Duvic M (1999) Pentostatin therapy of T-cell lymphomas with cutaneous manifestations. J Clin Oncol 17: 3117-3121

Lundin J, Hagberg H, Repp R, Cavallin-Stahl E, Freden S, Juliusson G, Rosenblad E, Tjonnfjord G, Wiklund T, Osterborg A (2003) Phase 2 study of alemtuzumab (anti-CD52 monoclonal antibody) in patients with advanced mycosis fungoides/Sezary syndrome. Blood 101: $4267-4272$

Lundin J, Osterborg A, Brittinger G, Crowther D, Dombret H, Engert A, Epenetos A, Gisselbrecht C, Huhn D, Jaeger U, Thomas J, Marcus R, Nissen N, Poynton C, Rankin E, Stahel R, Uppenkamp M, Willemze R, Mellstedt H (1998) CAMPATH-1H monoclonal antibody in therapy for previously treated low-grade non-Hodgkin's lymphomas: a phase II multicenter study. European Study Group of CAMPATH-1H Treatment in Low-Grade Non-Hodgkin's Lymphoma. J Clin Oncol 16: $3257-3263$

Marchi E, Alinari L, Tani M, Stefoni V, Pimpinelli N, Berti E, Pagano L, Bernengo MG, Zaja F, Rupoli S, Pileri S, Baccarani M, Zinzani PL (2005) Gemcitabine as frontline treatment for cutaneous T-cell lymphoma: phase II study of 32 patients. Cancer 104: 2437-2441

McFarlane V, Friedmann PS, Illidge TM (2005) What's new in the management of cutaneous T-cell lymphoma? Clin Oncol ( $R$ Coll Radiol) 17: $174-184$

Meech SJ, Edelson R, Walsh P, Norris DA, Duke RC (2001) Reversible resistance to apoptosis in cutaneous T cell lymphoma. Ann N Y Acad Sci 941: $46-58,46-58$

Mei S, Ho AD, Mahlknecht U (2004) Role of histone deacetylase inhibitors in the treatment of cancer (Review). Int J Oncol 25: 1509-1519

Miller AB, Hoogstraten B, Staquet M, Winkler A (1981) Reporting results of cancer treatment. Cancer 47: 207-214

Mitchell TJ, John S (2005) Signal transducer and activator of transcription (STAT) signalling and T-cell lymphomas. Immunology 114: $301-312$

Molina A, Zain J, Arber DA, Angelopolou M, O’Donnell M, Murata-Collins J, Forman SJ, Nademanee A (2005) Durable clinical, cytogenetic, and molecular remissions after allogeneic hematopoietic cell transplantation for refractory Sezary syndrome and mycosis fungoides. J Clin Oncol 23: $6163-6171$ 
Neely SM, Mehlmauer M, Feinstein DI (1987) The effect of isotretinoin in six patients with cutaneous T-cell lymphoma. Arch Intern Med 147: 529-531

Niwa R, Shoji-Hosaka E, Sakurada M, Shinkawa T, Uchida K, Nakamura K, Matsushima K, Ueda R, Hanai N, Shitara K (2004) Defucosylated chimeric anti-CC chemokine receptor 4 IgG1 with enhanced antibodydependent cellular cytotoxicity shows potent therapeutic activity to Tcell leukemia and lymphoma. Cancer Res 64: 2127-2133

Olsen E, Duvic M, Frankel A, Kim Y, Martin A, Vonderheid E, Jegasothy B, Wood G, Gordon M, Heald P, Oseroff A, Pinter-Brown L, Bowen G, Kuzel T, Fivenson D, Foss F, Glode M, Molina A, Knobler E, Stewart S, Cooper K, Stevens S, Craig F, Reuben J, Bacha P, Nichols J (2001) Pivotal phase III trial of two dose levels of denileukin diftitox for the treatment of cutaneous T-cell lymphoma. J Clin Oncol 19: 376-388

Olsen EA (2003) Interferon in the treatment of cutaneous T-cell lymphoma. Dermatol Ther 16: $311-321$

Onozuka T, Yokota K, Kawashima T, Shimada H, Kodama K, Kobayashi H, Shimizu H (2004) An elderly patient with mycosis fungoides successfully treated with chronic low-dose oral etoposide therapy. Clin Exp Dermatol 29: $91-92$

Piekarz RL, Robey R, Sandor V, Bakke S, Wilson WH, Dahmoush L, Kingma DM, Turner ML, Altemus R, Bates SE (2001) Inhibitor of histone deacetylation, depsipeptide (FR901228), in the treatment of peripheral and cutaneous T-cell lymphoma: a case report. Blood 98: 2865-2868

Ramsay DL, Lish KM, Yalowitz CB, Soter NA (1992) Ultraviolet-B phototherapy for early-stage cutaneous T-cell lymphoma. Arch Dermatol 128: 931 - 933

Rook AH, Gottlieb SL, Wolfe JT, Vowels BR, Sood SS, Niu Z, Lessin SR, Fox FE (1997) Pathogenesis of cutaneous T-cell lymphoma: implications for the use of recombinant cytokines and photopheresis. Clin Exp Immunol 107(Suppl 1): 16-20,16-20

Rook AH, Kuzel TM, Olsen EA (2003) Cytokine therapy of cutaneous T-cell lymphoma: interferons, interleukin-12, and interleukin-2. Hematol Oncol Clin North Am 17: 1435 -1448, ix

Rook AH, Suchin KR, Kao DM, Yoo EK, Macey WH, DeNardo BJ, Bromely PG, Geng Y, Junkins-Hopkins JM, Lessin SR (1999a) Photopheresis: clinical applications and mechanism of action. J Investig Dermatol Symp Proc 4: 85-90

Rook AH, Wood GS, Yoo EK, Elenitsas R, Kao DM, Sherman ML, Witmer WK, Rockwell KA, Shane RB, Lessin SR, Vonderheid EC (1999b) Interleukin-12 therapy of cutaneous T-cell lymphoma induces lesion regression and cytotoxic T-cell responses. Blood 94: $902-908$

Sallah S, Wan JY, Nguyen NP (2001) Treatment of refractory T-cell malignancies using gemcitabine. Br J Haematol 113: $185-187$

Seo N, Furukawa F, Tokura Y, Takigawa M (2003) Vaccine therapy for cutaneous T-cell lymphoma. Hematol Oncol Clin North Am 17: 1467 - 1474

Soligo D, Ibatici A, Berti E, Morandi P, Longhi E, Venegoni L, Corbellino M, Annaloro C, Robbiolo L, Della VA, Alessi E, Lambertenghi DG (2003) Treatment of advanced mycosis fungoides by allogeneic stem-cell transplantation with a nonmyeloablative regimen. Bone Marrow Transplant 31: $663-666$

Somech R, Izraeli S, Simon J (2004) Histone deacetylase inhibitors - a new tool to treat cancer. Cancer Treat Rev 30: $461-472$
Sommer VH, Clemmensen OJ, Nielsen O, Wasik M, Lovato P, Brender C, Eriksen KW, Woetmann A, Kaestel CG, Nissen MH, Ropke C, Skov S, Odum N (2004) In vivo activation of STAT3 in cutaneous T-cell lymphoma. Evidence for an antiapoptotic function of STAT3. Leukemia 18: $1288-1295$

Talpur R, Ward S, Apisarnthanarax N, Breuer-Mcham J, Duvic M (2002) Optimizing bexarotene therapy for cutaneous T-cell lymphoma. J Am Acad Dermatol 47: 672 -684

Turkson J (2004) STAT proteins as novel targets for cancer drug discovery. Expert Opin Ther Targets 8: 409-422

Ungerstedt JS, Sowa Y, Xu WS, Shao Y, Dokmanovic M, Perez G, Ngo L, Holmgren A, Jiang X, Marks PA (2005) Role of thioredoxin in the response of normal and transformed cells to histone deacetylase inhibitors. Proc Natl Acad Sci USA 102: 673-678

Vega F, Luthra R, Medeiros LJ, Dunmire V, Lee SJ, Duvic M, Jones D (2002) Clonal heterogeneity in mycosis fungoides and its relationship to clinical course. Blood 100: 3369-3373

Vonderheid EC, Tan ET, Kantor AF, Shrager L, Micaily B, Van Scott EJ (1989) Long-term efficacy, curative potential, and carcinogenicity of topical mechlorethamine chemotherapy in cutaneous $\mathrm{T}$ cell lymphoma. I Am Acad Dermatol 20: 416-428

Washington LT, Huh YO, Powers LC, Duvic M, Jones D (2002) A stable aberrant immunophenotype characterizes nearly all cases of cutaneous T-cell lymphoma in blood and can be used to monitor response to therapy. BMC Clin Pathol 2: 5

Wysocka M, Benoit BM, Newton S, Azzoni L, Montaner LJ, Rook AH (2004) Enhancement of the host immune responses in cutaneous T-cell lymphoma by CpG oligodeoxynucleotides and IL-15. Blood 104: $4142-4149$

Zackheim HS, Amin S, Kashani-Sabet M, McMillan A (1999) Prognosis in cutaneous T-cell lymphoma by skin stage: long-term survival in 489 patients. J Am Acad Dermatol 40: 418-425

Zackheim HS, Epstein Jr EH, Crain WR (1990) Topical carmustine (BCNU) for cutaneous T cell lymphoma: a 15-year experience in 143 patients. I Am Acad Dermatol 22: 802-810

Zackheim HS, Kashani-Sabet M, Amin S (1998) Topical corticosteroids for mycosis fungoides. Experience in 79 patients. Arch Dermatol 134: $949-954$

Zackheim HS, Kashani-Sabet M, McMillan A (2003) Low-dose methotrexate to treat mycosis fungoides: a retrospective study in 69 patients. $\mathrm{J} \mathrm{Am}$ Acad Dermatol 49: $873-878$

Zhang C, Duvic M (2003) Retinoids: therapeutic applications and mechanisms of action in cutaneous T-cell lymphoma. Dermatol Ther 16: $322-330$

Zhang C, Richon V, Ni X, Talpur R, Duvic M (2005) Selective induction of apoptosis by histone deacetylase inhibitor SAHA in cutaneous T-cell lymphoma cells: relevance to mechanism of therapeutic effect. J Invest Dermatol 125: 1045 - 1052

Zinzani PL, Baliva G, Magagnoli M, Bendandi M, Modugno G, Gherlinzoni F, Orcioni GF, Ascani S, Simoni R, Pileri SA, Tura S (2000) Gemcitabine treatment in pretreated cutaneous T-cell lymphoma: experience in 44 patients. J Clin Oncol 18: $2603-2606$ 